\title{
Az új, csökkentett dózisú, hazai gyártású influenzavakcina (FluArt) forgalomba hozatalát követő első szezonjának biztonságossági vizsgálata
}

\author{
Vajó Péter ${ }^{1}$ - Gyurján Orsolya dr. ${ }^{2}$ - Szabó Ágnes Mira dr. ${ }^{2}$ \\ Kalabay László $\mathrm{dr}^{3}{ }^{3}$. Vajó Zoltán $\mathrm{dr}^{3}{ }^{3}$. Torzsa Péter dr. ${ }^{3}$ \\ ${ }^{1}$ Debreceni Egyetem, Általános Orvostudományi Kar, Klinikai Központ, Debrecen \\ ${ }^{2}$ PRENET-ING Kft., Budaörs \\ ${ }^{3}$ Semmelweis Egyetem, Általános Orvostudományi Kar, Családorvosi Tanszék, Budapest
}

\begin{abstract}
Bevezetés: A jelenleg engedélyezett szezonális influenzavakcinák hatóanyaga szinte kizárólag hasított, alegység- vagy teljes influenzavírus, amelyek vírustörzsenként $15 \mu \mathrm{g}$ hemagglutinint tartalmaznak felnőtt, illetve 60 ug-ot idős betegek részére készült oltások esetében.

Célkitüzés: Jelen tanulmány a korábbi hazai prepandémiás és pandémiás influenzavakcinák tapasztalatai során, majd a szezonális influenzavakcina dóziskereső klinikai vizsgálatában alacsonyabb dózissal is immunogénnek bizonyult, új, $6 \mu \mathrm{g}$ hatóanyag-tartalmú influenzavakcina (FluArt) első szezonjának biztonságossági adatait vizsgálja.

Módszer: Az Európai Gyógyszerfelügyelet által előírt termékspecifikus aktív felügyelet értelmében az új vakcina piacra kerülését követően azonnal, beavatkozással nem járó, forgalomba hozatalt követő gyógyszerbiztonsági vizsgálat lebonyolítására került sor az előírt populáció bevonásával. A vizsgálat során az oltást követô mellékhatások gyakoriságbeli változásának, a gyakoriság esetleges növekedésének a megfigyelése és dokumentálása történt, annak érdekében, hogy a vakcina alkalmazásával kapcsolatos kockázatok megelőzhetővé, csökkenthetővé váljanak. A statisztikai analízis Fischer-teszttel történt, 95\%-os konfidenciaintervallum mellett.

Eredmények: Az 587 személy bevonásával elvégzett vizsgálatban 24 jelentett mellékhatásból nem jelent meg olyan, amely az eddigi klinikai fejlesztés, illetve a korábban alkalmazott $15 \mu \mathrm{g}$ hemagglutinintartalmú vakcinák vizsgálata során ne lett volna ismert. A klinikai adatbázishoz képest nem volt megfigyelhető a jelentkező mellékhatások gyakoriságában lényeges eltérés.

Következtetések: Az eredmények alapján elmondható, hogy az új influenzavakcina a forgalomba hozatalát követő első szezonjában biztonságosnak bizonyult. A vizsgálat megerősítette az új influenzavakcina eredményes alkalmazását. Orv Hetil. 2017; 158(49): 1953-1959.
\end{abstract}

Kulcsszavak: prospektív, farmakovigilancia, kohorsz, gyermekek, felnőttek, időskorúak

\section{Safety data of the new, reduced-dose influenza vaccine FluArt after its first season on the market}

Introduction: The currently licensed seasonal influenza vaccines contain split, subunit or whole virions, typically in amounts of $15 \mu \mathrm{g}$ hemagglutinin per virus strain for adult and up to $60 \mu \mathrm{g}$ in elderly patients.

Aim: The present study reports safety data of the newly licensed, reduced dose vaccine with $6 \mu \mathrm{g}$ of hemagglutinin per strain produced by Fluart (Hungary) after its first season on the market. The main objective of enhanced safety surveillance was to detect a potential increase in reactogenicity and allergic events that is intrinsic to the product in near real-time in the earliest vaccinated cohorts.

Method: The study methods were based on the Interim guidance on enhanced safety surveillance for seasonal influenza vaccines in the EU by the European Medicines Agency. Statistics: We used the Fisher exact test with 95\% confidence intervals. 
Results: We studied 587 patients and detected a total 24 adverse events, all of which have already been known during the licensing studies of the present vaccine. The frequencies of the adverse events were not different from what had been seen with the previously licensed $15 \mu \mathrm{g}$ vaccine.

Conclusions: Based on the results, the authors conclude that the new, reduced dose vaccine FluArt is safe and tolerable.

Keywords: prospective, pharmacovigilance, cohort, children, adults, elderly

Vajó P, Gyurján O, Szabó ÁM, Kalabay L, Vajó Z, Torzsa P. [Safety data of the new, reduced-dose influenza vaccine FluArt after its first season on the market]. Orv Hetil. 2017; 158(49): 1953-1959.

(Beérkezett: 2017. augusztus 6; elfogadva: 2017. szeptember 22.)

\section{Rövidítések}

EMA = European Medicines Agency; Eudra CT = European Clinical Trials Database; EU PAS = European Union electronic Register of Post-Authorisation Studies; MedDRA = Medical Dictionary for Regulatory Activities; OEK = Országos Epidemiológiai Központ; OKI = Országos Közegészségügyi Intézet; PASS $=$ Post-authorisation Safety Studies $;$ PT $=$ Preferred Term $;$ SOC $=$ System Organ Class $;$ WHO $=($ World Health Organization) Egészségügyi Világszervezet

A jelenleg engedélyezett szezonális influenzavakcinák hatóanyaga szinte kizárólag hasított vagy alegységvírus, amelyek vírustörzsenként $15 \mu \mathrm{g}$ hemagglutinint tartalmaznak felnőtt, illetve egyes esetekben $60 \mu \mathrm{g}$-ot idős betegek részére készült oltások esetében [1-3]. A 2009/2010-es szezonban megfigyelt oltóanyaghiány azonban felhívta a figyelmet arra, hogy a gyártókapacitás növelése és hatékonyabb vakcinák elóállítása feltétlenül szükséges gazdasági és népegészségügyi szempontból [4]. A legutóbbi pandémia során munkacsoportunk sikeresen kifejlesztett egy csökkentett, 6 ug dózisú monovalens pándémiás oltóanyagot, ami a kisebb hemagglutinintartalom mellett is kellő immunogenitással rendelkezett, lehetôvé téve ezzel a gyártókapacitás növelését [5]. Ezután a csökkentett, 6 g hemagglutinintartalmú, trivalens szezonális vakcina (FluArt) fejlesztése és engedélyeztetése is sikerrel járt $[6,7]$.

Jelen tanulmány a korábbi hazai prepandémiás és pandémiás influenzavakcinák tapasztalatai során, majd a szezonális influenzavakcina dóziskereső klinikai vizsgálatában hatásosnak bizonyult, $6 \mu \mathrm{g}$ hatóanyag-tartalmú influenzavakcina első hazai szezonjának biztonságossági vizsgálatát mutatja be. Az Európai Gyógyszerfelügyelet által elöírt termékspecifikus aktív felügyelet értelmében az új vakcina piacra kerülését követően azonnal, beavatkozással nem járó, forgalomba hozatalt követő gyógyszerbiztonsági vizsgálat lebonyolítására került sor az előírt populáció bevonásával. A vizsgálat célja az oltást követô mellékhatások gyakoriságbeli változásának, a gyakoriság esetleges növekedésének a megfigyelése és dokumentálása volt annak érdekében, hogy a vakcina alkalma- zásával kapcsolatos kockázatok megelőzhetővé, csökkenthetôvé váljanak.

A szezonális influenzaepidémiák idején világviszonylatban a populáció 5-15\%-a fertőződik meg. Magyarországon az Országos Közegészségügyi Intézet (OKI, korábban: Országos Epidemiológiai Központ - OEK) által múködtetett nemzeti influenzafigyelő szolgálat adatai szerint 100 000-ből körülbelül 2900 személyt érint évente az influenzaszerű megbetegedés [8]. Az úgynevezett magas kockázatú csoportokban a vírusfertőzés az alapbetegségek súlyosbodásához, valamint szövődmények kialakulásához vezethet. Magas kockázatú csoportokba sorolhatók többek között a májkárosodásban, vesekárosodásban, idült légúti betegségekben, idült szív-ér rendszeri betegségekben, veleszületett vagy szerzett immunhiányos állapotokban (például HIV-pozitív és aktív daganatos betegségben), vagy anyagcserezavarokban (például diabetes) szenvedő betegek. A várandós vagy terhességet tervezô nők, hosszú távú szalicilátkezelésben részesülő gyermekek és serdülők, idősek és gondozásra szoruló betegek esetén a kockázat szintén magasnak tekinthető. Az OKI javasolja az önkéntes védőoltás éves alkalmazását, amelynek beadása még a járvány kitörése elött ajánlott, mivel a védettség a szervezet aktív reakciója során, az oltást követően két-három hét elteltével alakul ki. A szezonális influenzavakcinák alkalmazása különösen a magas kockázatú csoportok számára ajánlott, az OKI által minden évben kiadott, védőoltásokról szóló módszertani levelében meghatározott populációkban a védőoltás térítésmentesen alkalmazható $[9,10]$.

Az oltásokban található vírustörzsek összetétele minden évben a WHO és az EMA által meghatározott és kihirdetett influenza-vírustörzseknek megfelelően alakul [11].

Az Európai Gyógyszerkönyv eloórásának megfelelően évekig a vírustörzsenként $15 \mu \mathrm{g}$ hemagglutinintartalmú szezonális influenzavakcinák voltak a piacvezetők. A gyógyszerkönyvi előírás megengedi eltérő hatóanyagtartalmú vakcinák forgalomba hozatalát, amennyiben más hatóanyag-tartalmú készítmény alkalmazása klinikai vizsgálatokkal alátámasztható. Erre alapozva a vakcinafejlesztés során dóziskereső vizsgálatokat végeztünk a 3,$5 ; 6 ; 9 ; 15 \mu g$ hemagglutinintartalmú klinikai vizsgála- 
ti készítményekkel, amelyek közül a $6 \mu \mathrm{g}$ hatóanyag-tartalmú készítmény bizonyult a leginkább megfelelőnek hatásosság és biztonságosság szempontjából. A használt technológia mellett a hatóanyag-tartalom növelése az immunválaszban további növekedést nem okozott [7]. A fejlesztést alátámasztotta az általunk korábban, szintén $6 \mu \mathrm{g}$ hatóanyag-tartalmú pandémiás (H1Nl) influenzavakcinákkal folytatott klinikai vizsgálatok eredménye, valamint a 2009. évi pandémia idején alkalmazott oltóanyag vírusfertőzéssel szembeni hatékonysága [5-7, 12-15]. A klinikai vizsgálati készítmények eredményei alapján az új, $6 \mu \mathrm{g}$ hatóanyag-tartalmú készítmény forgalomba hozatali engedély megszerzését követően (OGYIT-8998/03) a 2015/2016-os szezonban került először a piacra, 3FluArt néven.

Az EMA által meghatározottak alapján a szezonális influenzavakcinákra előírt termékspecifikus aktív felügyelet értelmében a biztonságosságának igazolása céljából a készítmény szezonális piacra kerülését követően azonnal, beavatkozással nem járó, forgalomba hozatalt követő gyógyszerbiztonsági vizsgálatot (PASS) kell megkezdeni és azt az előírt populáció bevonásával elvégezni $[16,17]$.

\section{Célkitüzés}

A PASS vizsgálat célkitűzése a vizsgálatba bevont személyek által az oltást követően észlelt mellékhatások megfigyelése, ismert gyakoriságuk változásának, esetleges növekedésének vizsgálata annak érdekében, hogy a vakcina alkalmazásával kapcsolatos kockázatok megelőzhetővé, csökkenthetővé váljanak [16].

\section{Módszer}

Az EMA által meghatározott előírásnak megfelelő termékspecifikus aktív felügyelet értelmében a forgalomba hozatalt követő biztonságossági vizsgálat gyermek, serdülő, felnőtt és időskorú személyek meghatározott populációit célozza meg [16]. A 2015/2016-os influenzaszezonra meghatározott vírustörzseket tartalmazó, a rutin orvosi gyakorlat szerint alkalmazott új influenzavakcinával (FluArt) való oltást követően a vizsgálati terv szerint - 20\% kiesési aránnyal számolva - maximum 600 személy bevonását terveztük. Fentiek alapján a meghatározott gyermek, serdülő, felnőtt és időskorú korcsoportok megoszlása a következők szerint alakult: 3-12 éves gyermekek: 100-120 fó, 13-17 éves serdülők: 100-120 fó, 18-65 éves felnőttek: 150-180 fö, 65 év feletti időskorúak: 150-180 fó.

A rutin orvosi gyakorlat szerinti oltás előtt az oltott személyek a betegtájékoztató és beleegyező nyilatkozat aláírásával kifejezett részvételi szándék esetén a vizsgálatba bevonásra kerültek. Az oltást követően azonnal jelentkező mellékhatások megfigyelése érdekében a beoltott és vizsgálatba bevont személyeket az oltást követően hét nappal telefonon kereste meg oltó orvosuk az oltást követően tapasztalt nemkívánatos események dokumentálása céljából [16].

A klinikai vizsgálati tapasztalatok alapján a hétnapos megfigyelés alatt az alábbi események megjelenését vizsgáltuk (a későbbiekben reaktogenitási végpontoknak nevezve): fájdalom az oltás helyén, oltási helyen bőrpír, oltási hely duzzanata, oltási hely keménysége, oltási hely bevérzése, urticaria, bőrpír, fejfájás, hőemelkedés/láz, rossz közérzet, hidegrázás, fáradékonyság, verejtékezés, sápadtság, szédülés, zsibbadás, rekedtség, hányinger, izomfájdalom, ízületi fájdalom, végtagfájdalom, hiperszenzitivitási reakciók, beleértve a szemészeti tüneteket is. Az utánkövetés során dokumentáltuk a vény nélküli gyógyszer alkalmazását, illetve a fent felsorolt eseményektől való eltérést [16]. A rögzített adatok alapján meghatározásra kerültek a készítménnyel ok-okozati összefüggésben álló mellékhatások.

A vizsgálat a magyar és nemzetközi szabályozásnak és gyakorlatnak megfelelően került lebonyolításra [16-23], 16 magyarországi vizsgálóhelyen, gyermek-, felnőtt- és vegyes praxisú háziorvosi rendelő bevonásával.

\section{Eredmények}

A PASS vizsgálatba összesen 587 személy került bevonásra, ami a meghatározott gyermek, serdülő, felnőtt és időskorú korcsoport között a következők szerint alakult: 3-12 éves gyermekek: 121 fö, 13-17 éves serdülők:

1. táblázat |Vizsgálati populáció

\begin{tabular}{lcccc}
\hline Korcsoport $^{(1)}$ & $\begin{array}{c}\text { Vizsgálatba } \\
\text { bevont } \\
\text { személyek } \\
\text { száma }^{(2)}\end{array}$ & $\begin{array}{c}\text { Vizsgálatban } \\
\text { utánkövetett } \\
\text { személyek } \\
\text { száma }^{(3)}\end{array}$ & $\begin{array}{c}\text { Minimálisan } \\
\text { tervezett } \\
\text { vizsgálati } \\
\text { populáció }\end{array}$ & $\begin{array}{c}\text { Maximálisan } \\
\text { tervezett } \\
\text { vizsgálati } \\
\text { populáció }\end{array}$ \\
\hline 3-12 éves & 121 & 121 & 100 & 120 \\
13-17 éves & 105 & 105 & 100 & 120 \\
18-65 éves & 180 & 180 & 150 & 180 \\
$>65$ éves & 181 & 180 & 150 & 180 \\
\hline Összesen & 587 & 586 & 500 & 600 \\
\hline
\end{tabular}

(1)3-12 éves: A résztvevő 3-12 éves gyermek korcsoportba tartozik, amennyiben a 3 . életévét már betöltötte, de még nem töltötte be a 13. életévét a bevonás napján.

13-17 éves: A résztvevő 13-17 éves serdülő korcsoportba tartozik, amennyiben a 13. életévét már betöltötte, de még nem töltötte be a 18. életévét a bevonás napján.

18-65 éves: A résztvevő 18-65 éves felnőtt korcsoportba tartozik, amennyiben a 18 . életévét már betöltötte, de még nem töltötte be a 65 . életévét a bevonás napján.

$>65$ éves: A résztvevő 65 év feletti időskorú korcsoportba tartozik, amennyiben a 65 . életévét már betöltötte a bevonás napján.

${ }^{(2)}$ Vizsgálatba bevont személyek: A 3Fluart influenzavakcinával beoltott, résztvevői tájékoztatót és beleegyező nyilatkozatot aláírt személyek.

${ }^{(3)}$ Vizsgálatban utánkövetett személyek: Azok a vizsgálatba bevont személyek, akiket az oltást követő 7 . napon történő telefonos megkeresés során elért az oltó orvosuk. 
2. táblázat | Nemkívánatos események előfordulási gyakorisága intenzitás és korcsoport szerinti lebontásban

\begin{tabular}{lccccc}
\hline Korcsoport $^{(1)}$ & \multicolumn{3}{c}{ Nemkívánatos események intenzitása $^{*}$ Összesen } \\
\cline { 2 - 5 } & Enyhe $^{(2)}$ & Közepes $^{(3)}$ & Súlyos $^{(4)}$ & $\begin{array}{c}\text { Élet- } \\
\text { veszélyes }^{(5)}\end{array}$ & \\
\hline 3-12 éves & 13 & 2 & 0 & 0 & 15 \\
13-17 éves & 5 & 1 & 0 & 0 & 6 \\
18-65 éves & 0 & 3 & 0 & 0 & 3 \\
$>65$ éves & 0 & 4 & 0 & 1 & 5 \\
\hline Összesen & 18 & 10 & 0 & 1 & 29
\end{tabular}

(1)3-12 éves: A résztvevő 3-12 éves gyermek korcsoportba tartozik, amennyiben a 3 . életévét már betöltötte, de még nem töltötte be a 13. életévét a bevonás napján.

13-17 éves: A résztvevő 13-17 éves serdülő korcsoportba tartozik, amennyiben a 13. életévét már betöltötte, de még nem töltötte be a 18. életévét a bevonás napján.

18-65 éves: A résztvevő 18-65 éves felnőtt korcsoportba tartozik, amennyiben a 18. életévét már betöltötte, de még nem töltötte be a 66. életévét a bevonás napján.

>65 éves: A résztvevő 65 év feletti időskorú korcsoportba tartozik, amennyiben a 65 . életévét már betöltötte a bevonás napján.

${ }^{(2)}$ Enyhe: átmeneti vagy enyhe diszkomfortérzés, nincs aktivitásbeli korlátozottság, nincs szükség segítségkérésre, orvosi beavatkozás/ kezelés nem szükséges, nincs szükség kórházi ápolásra.

${ }^{(3)}$ Közepes: enyhe, illetve mérsékelt aktivitásbeli korlátozottság, némi segítségkérésre szükség lehet, nem vagy minimális orvosi beavatkozás/kezelés szükséges, nincs szükség kórházi ápolásra.

${ }^{(4)}$ Súlyos: kifejezett aktivitásbeli korlátozottság, segítség kérése általában szükséges, orvosi beavatkozás/kezelés szükséges, kórházi ápolás lehetséges.

${ }^{(5)}$ Életveszélyes: extrém aktivitásbeli korlátozottság, segítség kérése kifejezetten szükséges, jelentős orvosi beavatkozás/kezelés szükséges, kórházi ápolás valószínú.

105 fó, 18-65 éves felnőttek: 180 fö, 65 év feletti időskorúak: 181 fö (EU PAS szám: EUPAS10350).

Minden vizsgálati alany elérhető volt az utánkövetés során, egy résztvevő kivételével, a készítménnyel nem összefüggő fatális esemény következtében. A vizsgálati tervben meghatározott és a tényleges bevonási arányt az 1. táblázat szemlélteti.

A vizsgálat során összesen 29 nemkívánatos eseményt jelentettek, amelyből 18 enyhe és 10 közepes intenzitású, néhány napon belül, szövődmény nélkül gyógyuló volt. További egy esetben halálesemény került dokumentálásra, amelynek oka szívelégtelenség volt. A nemkívánatos események előfordulási gyakoriságát intenzitásuk és korcsoportonkénti megoszlásuk szerint a 2. táblázat mutatja be.

Összességében véve az 587 résztvevő esetében 29 eseményből 24 volt a készítménnyel összefüggőnek ítélt mellékhatás, amelyek a következők voltak: hányinger, végtagfájdalom, oltási hely fájdalma, oltási helyen bőrpír, oltási hely duzzanata, oltási hely keménysége, oltási hely bevérzése, láz, rossz közérzet, fáradékonyság, bőrkiütés, valamint vény nélküli gyógyszeres kezelés. Ezek közül egy mellékhatás (kiütés) nem tartozott a reaktogenitási végpontok közé.
A mellékhatások előfordulási gyakoriságát az azonos korcsoportokat lefedô klinikai vizsgálatok adataiból származó mellékhatások előfordulási gyakoriságával hasonlítottuk össze (EudraCT: 2013-003449-40; EudraCT: 2011-003314-16). Az összehasonlítás Fischer-teszttel történt, 95\%-os konfidenciaintervallum mellett. A vizsgálatban előfordult mellékhatások előfordulási gyakoriságában lényegesen alacsonyabb értékeket figyeltünk meg a klinikai vizsgálatok adataihoz képest. A 3. táblázat alapján elmondható, hogy az összesített adatbázis tekintetében az eredmény statisztikailag szignifikánsnak minősült. Diagnózisokra lebontva, az eltérés szignifikáns volt a fejfájás, izomfájdalom, oltási hely fájdalma, oltási helyen bőrpír, oltási hely duzzanata, oltási hely keménysége, rossz közérzet esetében. A korcsoportok között jelentős eltérés nem volt.

A vizsgálatban megfigyelt mellékhatások előfordulási gyakoriságát továbbá a klinikai vizsgálati adatbázis, azaz az új influenzavakcina fejlesztése során végzett klinikai vizsgálatok összesített adatbázisa alapján meghatározott gyakoriságokkal hasonlítottuk össze. A gyakoriságokban jelentős eltérést nem tapasztaltunk. A vizsgálatban a hétnapos utánkövetés során nem jelent meg a klinikai vizsgálatok és az azonos gyártástechnológiával készült, magasabb, $15 \mu \mathrm{g}$ hatóanyag-tartalmú influenzavakcinával (Fluval, Omninvest) kapcsolatban nem várt mellékhatás. Az összehasonlítás céljából kizárólag deskriptív elemzés készült.

\section{Megbeszélés}

A szezonális influenzavakcinák különleges kihívást jelentenek farmakovigilancia szempontjából. Ennek oka többek között a nagy populációk tömeges immunizálása viszonylag rövid idő alatt, szezonális tényezők, a megelőzendő betegség és a vakcina által kiváltott mellékhatások hasonlósága [16]. Mindezek miatt igen fontos az új oltóanyagok gyors és alapos farmakovigilancia-vizsgálata, az esetleges új biztonságossági problémák mielóbbi felfedezése céljából, lehetőleg még a járványszezon tetőzése elött.

A jelen vizsgálat eredményei alapján elmondható, hogy az új FluArt influenzavakcina piacra kerülését követően közvetlenül megkezdett, 587 személy bevonásával elvégzett PASS vizsgálatban nem jelent meg olyan mellékhatás, ami a klinikai fejlesztés során nem volt előzőleg ismert. A klinikai adatbázishoz képest nem volt megfigyelhető a jelentkező mellékhatások gyakoriságában lényeges eltérés, de ezek is a védőoltás beadását ritkán kíséró, spontán szúnő oltási reakciók, amelyek az immunizációs folyamat jelei. A vizsgálati eredmények alapján elmondható, hogy az új, csökkentett dózisú influenzavakcina a forgalomba hozatalát követő első szezonjában biztonságosnak bizonyult az előírt populációban vizsgálva.

A készítmény biztonságosságát tovább erősíti a vírustörzsenként $15 \mu \mathrm{g}$ és $6 \mu \mathrm{g}$ hatóanyag-tartalmú influenza- 
Mellékhatások eloszlása a beavatkozással nem járó, forgalomba hozatalt követő gyógyszerbiztonsági vizsgálat és az azonos korcsoportokat vizsgáló, fejlesztés során végzett klinikai vizsgálatok között korcsoportok és diagnózis szerint

\begin{tabular}{|c|c|c|c|c|c|c|c|}
\hline \multirow{3}{*}{$\begin{array}{l}\text { MedDRA-kód }^{(4)} \\
\mathrm{SOC}^{(5)} / \mathrm{PT}^{(6)}\end{array}$} & \multicolumn{2}{|c|}{18 év alatti személyek } & \multicolumn{2}{|c|}{18 év feletti személyek } & \multicolumn{2}{|c|}{ Összesen } & \multirow[t]{2}{*}{ P-érték ${ }^{(7)}$} \\
\hline & Vizsgálat ${ }^{(1)}$ & $\begin{array}{c}\text { Klinikai } \\
\text { vizsgálat } \mathrm{l}^{(2)}\end{array}$ & Vizsgálat ${ }^{(1)}$ & $\begin{array}{c}\text { Klinikai } \\
\text { vizsgálat } 2^{(3)}\end{array}$ & Vizsgálat ${ }^{(1)}$ & $\begin{array}{c}\text { Klinikai } \\
\text { vizsgálat } 1-2^{(2,3)}\end{array}$ & \\
\hline & 226 & 120 & 361 & 601 & 587 & 721 & n. a. \\
\hline \multicolumn{8}{|c|}{ Reaktogenitási végpontként meghatározott mellékhatások ${ }^{(8)}$} \\
\hline \multicolumn{8}{|l|}{ Idegrendszeri betegségek és tünetek } \\
\hline Fejfájás & $0(0,00 \%)$ & $4(3,33 \%)$ & $0(0,00 \%)$ & $15(2,50 \%)$ & $0(0,00 \%)$ & $19(2,64 \%)$ & $1,61 \mathrm{e}-05$ \\
\hline Szédülés & $0(0,00 \%)$ & $0(0,00 \%)$ & $0(0,00 \%)$ & $1(0,17 \%)$ & $0(0,00 \%)$ & $1(0,14 \%)$ & 1,00 \\
\hline Zsibbadás & $0(0,00 \%)$ & $0(0,00 \%)$ & $0(0,00 \%)$ & $1(0,17 \%)$ & $0(0,00 \%)$ & $1(0,14 \%)$ & 1,00 \\
\hline \multicolumn{8}{|c|}{ Emésztörendszeri betegségek és tünetek } \\
\hline Hányinger & $1(0,44 \%)$ & $0(0,00 \%)$ & $0(0,00 \%)$ & $1(0,17 \%)$ & $1(0,17 \%)$ & $1(0,14 \%)$ & 1,00 \\
\hline Hányás & $0(0,00 \%)$ & $1(0,83 \%)$ & $0(0,00 \%)$ & $0(0,00 \%)$ & $0(0,00 \%)$ & $1(0,14 \%)$ & 1,00 \\
\hline Hasi fájdalom & $0(0,00 \%)$ & $1(0,83 \%)$ & $0(0,00 \%)$ & $0(0,00 \%)$ & $0(0,00 \%)$ & $1(0,14 \%)$ & 1,00 \\
\hline \multicolumn{8}{|c|}{ A csont- és izomrendszer, valamint a kötöszöpet betegségei és tünetei } \\
\hline Izomfájdalom & $0(0,00 \%)$ & $12(10,00 \%)$ & $0(0,00 \%)$ & $19(3,16 \%)$ & $0(0,00 \%)$ & $31(4,30 \%)$ & $7,55 \mathrm{e}-09$ \\
\hline Végtagfájdalom & $1(0,44 \%)$ & $0(0,00 \%)$ & $0(0,00 \%)$ & $0(0,00 \%)$ & $1(0,17 \%)$ & $0(0,00 \%)$ & 0,449 \\
\hline \multicolumn{8}{|c|}{ Általános tünetek, az alkalmazás helyén fellépö reakciók } \\
\hline Oltási hely fájdalma & $3(1,33 \%)$ & $38(31,67 \%)$ & $5(1,39 \%)$ & $135(22,46 \%)$ & $8(1,36 \%)$ & $173(23,99 \%)$ & $7,44 \mathrm{e}-39$ \\
\hline Oltási helyen bőrpír & $3(1,33 \%)$ & $9(7,5 \%)$ & $1(0,28 \%)$ & $60(9,98 \%)$ & $4(0,68 \%)$ & $69(9,57 \%)$ & $2,34 \mathrm{e}-14$ \\
\hline Oltási hely duzzanata & $2(0,89 \%)$ & $9(7,5 \%)$ & $0(0,00 \%)$ & $47(7,82 \%)$ & $2(0,34 \%)$ & $56(7,77 \%)$ & $7,98 \mathrm{e}-13$ \\
\hline Oltási hely keménysége & $0(0,00 \%)$ & $8(6,67 \%)$ & $0(0,00 \%)$ & $54(8,99 \%)$ & $0(0,00 \%)$ & $62(8,60 \%)$ & $3,09 \mathrm{e}-17$ \\
\hline Oltási hely bevérzése & $0(0,00 \%)$ & $2(1,67 \%)$ & $1(0,28 \%)$ & $3(0,50 \%)$ & $1(0,17 \%)$ & $5(0,69 \%)$ & 0,232 \\
\hline Láz & $2(0,89 \%)$ & $3(2,5 \%)$ & $0(0,00 \%)$ & $10(1,66 \%)$ & $2(0,34 \%)$ & $13(1,80 \%)$ & 0,0165 \\
\hline Rossz közérzet & $\mathrm{l}(0,44 \%)$ & $8(6,67 \%)$ & $0(0,00 \%)$ & $20(3,33 \%)$ & $1(0,17 \%)$ & $28(3,88 \%)$ & $1,09 \mathrm{e}-06$ \\
\hline Fáradékonyság & $2(0,89 \%)$ & $0(0,00 \%)$ & $0(0,00 \%)$ & $0(0,00 \%)$ & $2(0,34 \%)$ & $0(0,00 \%)$ & 0,201 \\
\hline Hidegrázás & $0(0,00 \%)$ & $1(0,83 \%)$ & $0(0,00 \%)$ & $8(1,33 \%)$ & $0(0,00 \%)$ & $9(1,25 \%)$ & 0,00531 \\
\hline \multicolumn{8}{|l|}{ Mütéti és orvosi eljárások } \\
\hline Gyógyszeres kezelés (vény nélküli) & $1(0,44 \%)$ & $0(0,00 \%)$ & $0(0,00 \%)$ & $0(0,00 \%)$ & $\mathrm{l}(0,17 \%)$ & $0(0,00 \%)$ & 0,449 \\
\hline \multicolumn{8}{|c|}{ Reaktogenitási végpontként nem meghatározott mellékhatások ${ }^{(9)}$} \\
\hline \multicolumn{8}{|l|}{ A bör és kötöszöovet betegségei és tünetei } \\
\hline Bőrkiütés & $1(0,44 \%)$ & $0(0,00 \%)$ & $0(0,00 \%)$ & $0(0,00 \%)$ & $1(0,17 \%)$ & $0(0,00 \%)$ & 0,449 \\
\hline Öszesen & $17(7,52 \%)$ & $96(80,00 \%)$ & $7(1,94 \%)$ & $374(62,23 \%)$ & $24(4,09 \%)$ & $470(65,19 \%)$ & $2,58 e-132$ \\
\hline
\end{tabular}

${ }^{(1)}$ Vizsgálat: Prospektív, beavatkozással nem járó, kohorszvizsgálat a készítmény biztonságosságának követése céljából a vakcinával beoltott gyermek, serdülő, felnőtt és időskorú személyeknél (EU PAS szám: EUPAS10350).

${ }^{(2)}$ Klinikai vizsgálat 1: A törzsenként $6 \mu \mathrm{g} \mathrm{HA} / 0,5 \mathrm{ml}$ hatóanyag-tartalmú trivalens, szezonális Fluval AB Novo szuszpenziós injekció (influenzavakcina) immunogenitásának és tolerálhatóságának vizsgálata gyermekekben és serdülőkben (EudraCT-szám: 2013-003449-40).

${ }^{(3)}$ Klinikai vizsgálat 2: Randomizált, kettős vak, multicentrikus vizsgálat az egy adag Fluval AB-szerú influenzavakcina (trivalens, teljes vírust és alumínium-foszfát adjuvánst tartalmazó, aktív hatóanyag-tartalom: $6 \mu \mathrm{g}$ HA a szezonális A/H1N1, A/H3N2, és B influenza-antigénekbőll) tolerabilitásának és immunogenitásának vizsgálata felnőttek és időskorúak esetében (EudraCT-szám: 2011-003314-16).

${ }^{(4)}$ MedDRA: Az egységes hatósági kommunikációt támogató terminológia (fizikai tünetek, diagnózisok, vizsgálatok, beavatkozások meghatározása, csoportosítása).

${ }^{5}$ SOC: Szervrendszerszintû terminológia.

${ }^{(6)} \mathrm{PT}$ : Élettani-kórtani szempontból pontos, egységes terminológia.

${ }^{(7)}$-érték: szignifikanciaszint.

${ }^{(8)}$ Reaktogenitási végpontként meghatározott mellékhatások: Mellékhatás a gyógyszerek által kiváltott káros és nem kívánt hatás. Mellékhatásnak minősülnek a gyógyszerek szokásos adagolása során a forgalomba hozatali engedély szerinti alkalmazásból eredő káros és nem kívánt hatásokon kívül a gyógyszerelési hibából, valamint a forgalomba hozatali engedélyben nem szereplő felhasználásból eredő káros, nem kívánt hatások is, beleértve a gyógyszer helytelen használatát és az azzal való visszaélést. A reaktogenitási végpontok a következő́k voltak: oltási hely fájdalma, oltási helyen bő́rír, oltási hely duzzanata, oltási hely keménysége, oltási hely bevérzése, urticaria, bőrpír, fejfájás, hőemelkedés/láz, rossz közérzet, hidegrázás, fáradékonyság, verejtékezés, sápadtság, szédülés, zsibbadás, rekedtség, hányinger, izomfájdalom, ízületi fájdalom, végtagfájdalom, hiperszenzitivitási reakciók, beleértve a szemészeti tüneteket is, fájdalom és láz csökkentésére szolgáló vény nélküli gyógyszer alkalmazására.

${ }^{(9)}$ Reaktogenitási végpontként nem meghatározott mellékhatások: azok a mellékhatások, amelyek reaktogenitási végpontként nem kerülttek meghatározásra.

A statisztikai elemzés alapján a „vizsgálat”-ban előforduló mellékhatások előfordulási gyakorisága (4,09\% vs. 65,19\%) a „klinikai vizsgálat 1-2”-vel összehasonlításban lényegesen alacsonyabb volt. Az összesített adatbázis tekintetében az eredmény szignifikáns volt, 2,58e-132 p-értékkel. Diagnózisokra lebontva az eltérés szignifikáns fejfájás, izomfájdalom, oltási hely fájdalma, oltási helyen bőrpír, oltási hely duzzanata, oltási hely keménysége, rossz közérzet esetében. 
vakcinák alapjaiban véve hasonló felépítésú, forgalomba hozatalt követő gyógyszerbiztonsági vizsgálata során jelentett mellékhatások, amelyek jellegükben és előfordulási gyakoriságukban jelentős eltérést nem mutattak.

\section{Következtetések}

Elmondható, hogy a vizsgálat az új, $6 \mu g$ hemagglutinintartalmú influenzavakcina eredményes alkalmazását támasztja alá, amely a tapasztalatok alapján a vírustörzsenként $15 \mu \mathrm{g}$ hemagglutinint tartalmazó, tojáson szaporított, inaktivált és adjuvált influenzavakcina (Fluval, Omninvest) megfelelő utódjának bizonyult. Ez lehetővé teszi a gyártókapacitás növelését, aminek jelentős gazdasági és népegészségügyi jelentősége van.

Anyagi támogatás: A közlemény megírása anyagi támogatásban nem részesült.

Szerzối munkamegosztás: V. Z.: A kézirat elkészítése, irodalmak gyújtése és feldolgozása. Gy. O., Sz. Á. M.: Statisztikai próbák, adatfeldolgozás. V. P.: Számítástechnikai feladatok, táblázatok elkészítése, irodalomjegyzék, kézirat formai rendezése, fordítás. T. P.: Betegbevonás, betegkövetés, adatgyújtés, kézirat elkészítése. K. L.: A kézirat végső formába öntése, munka koordinálása. A cikk végleges változatát valamennyi szerző elolvasta és jóváhagyta.

Érdekeltségek: A szerző́knek nincsenek érdekeltségeik.

\section{Irodalom}

[1] World Health Organization, 2005. Technical Report Series, No. 927, Annex 3. Recommendations for the production and control of influenza vaccine (inactivated). Available from: http://www. who.int/biologicals/publications/trs/areas/vaccines/influenza/ANNEX 3 InfluenzaP99-134.pdf [accessed: July 24, 2017].

[2] Couch RB, Winokur P, Brady R, et al. Safety and immunogenicity of a high dosage trivalent influenza vaccine among elderly subjects. Vaccine 2007; 25: 7656-7663.

[3] Chaloupka I, Schuler A, Marschall M, et al. Comparative analysis of six European influenza vaccines. Eur J Clin Microbiol Infect Dis. 1996; 15: 121-127.

[4] Kempe A, Daley MF, Stokley S, et al. Impact of a severe influenza vaccine shortage on primary care practice. Am J Prev Med. 2007; 33: 486-491

[5] Vajo Z, Tamas F, Sinka L, et al. Safety and immunogenicity of a 2009 pandemic influenza A HINl vaccine when administered alone or simultaneously with the seasonal influenza vaccine for the 2009-10 influenza season: a multicentre, randomised controlled trial. Lancet $2010 ; 375$ : 49-55.

[6] Vajo Z, Tamas F, Jankovics I. A reduced-dose seasonal trivalent influenza vaccine is safe and immunogenic in adult and elderly patients in a randomised controlled trial. Clin Vaccine Immunol. 2012; 19: 313-318.

[7] Vajo Z, Balaton G, Vajo P, et al. Dose sparing and lack of a doseresponse relationship with an influenza vaccine in adult and elderly patients - A randomised, double-blind clinical trial. Br J Clin Pharmacol. 2017; 83: 1912-1920.
[8] Report of the National Epidemiology Center of the Influenza Surveillance Service, Hungary, 14th Week of 2017. [Az Országos Epidemiológiai Központ tájékoztatója az influenza figyelőszolgálat adatairól, Magyarország, 2017, 14. hét.] Available from: https://www.antsz.hu/data/cms81692/Inf_2017. 14.het_honlap.pdf [accessed: July 24, 2017]. [Hungarian]

[9] Guidelines of the National Epidemiology Center regarding vaccines for 2015. [Az Országos Epidemiológiai Központ módszertani levele a 2015. évi védőoltásokról.] EPINFO 2015; 22(Suppl 1), 2015. március 30. [Hungarian]

[10] Advisory of the National Chief Medical Officer for the preparation for the 2015/16 influenza season. [Az országos tisztiföorvos körlevele a 2015/2016. évi influenzaszezonra történő felkészülésról.] EPINFO 2015; 22(42-43), 2015. október 30. [Hungarian]

[11] European Medicines Agency. BWP Ad-hoc Influenza Working Group - Amended EU recommendations for the seasonal influenza vaccine composition for the season 2015/2016. EMA/ CHMP/BWP/305331/2015. Available from: http://www. ema.europa.eu/docs/en_GB/document_library/Other/2015/03/WC500184916.pdf

[12] Vajo Z, Wood J, Kosa L, et al. A single-dose influenza A (H5Nl) vaccine safe and immunogenic in adult and elderly patients: an approach to pandemic vaccine development. J Virol. 2010; 84: 1237-1242.

[13] Vajo Z, Kosa L, Visontay I, et al. Inactivated whole virus influenza A (H5Nl) vaccine. Emerg Infect Dis. 2007; 13: 807-808.

[14] Vajo Z, Kosa L, Szilvasy I, et al. Safety and immunogenicity of a prepandemic influenza $A(\mathrm{H} 5 \mathrm{Nl})$ vaccine in children. Pediatr Infect Dis J. 2008; 27: 1052-1056.

[15] Vajo Z, Kosa L, Szilvasy I, et al. Yearly licensing studies from 1997 to 2007 of the inactivated whole virus seasonal influenza vaccine fluval - a useful approach to pandemic vaccine development even in less well developed countries? Influenza Other Respir Viruses 2008; 2: 221-228.

[16] European Medicines Agency. Interim guidance on enhanced safety surveillance for seasonal influenza vaccines in the EU. EMA/PRAC/222346/2014 (2014). Available from: http:// www.ema.europa.eu/docs/en_GB/document_library/Scientific_guideline/2014/04/WC500165492.pdf (accessed: July 24, 2017).

[17] European Medicines Agency. Explanatory note on the withdrawal of the note for guidance on harmonisation of requirements for influenza vaccines and of the core SmPC/PL for inactivated seasonal influenza vaccines. EMA/CHMP/VWP/ 40560/2014. Available from: http://www.ema.europa.eu/ docs/en_GB/document_library/Scientific_guideline/2014/ 02/WC500161022.pdf (accessed: July 24, 2017).

[18] European Medicines Agency. Guideline on good pharmacovigilance practices (GVP). Product- or Population-Specific Considerations I: Vaccines for prophylaxis against infectious diseases. EMA/488220/2012. Available from: http://www.ema.europa. $\mathrm{eu} / \mathrm{docs} / \mathrm{en}$ _GB /document_library/Scientific_guideline /2013/12/WC500157839.pdf (accessed: July 24, 2017).

[19] European Medicines Agency. Guideline on good pharmacovigilance practices (GVP). Module VIII - Post-authorization safety studies (Rev 3). EMA/813938/2011 Rev 3 (2013). Available from: http://www.ema.europa.eu/docs/en_GB/document_library/_guideline/2012/06/WC500Scientific.pdf (accessed: Nov 24, 2017).

[20] The Council of the European Communities. Council Regulation (EEC) 2309/93 of 22 July 1993 laying down Community procedures for the authorization and supervision of medicinal products for human and veterinary use and establishing a European Agency for the Evaluation of Medicinal Products. OJ No L 214 of 24.8.1993. Available from: http://ec.europa.eu/health// 
sites/health/files/files/eudralex/vol-1/reg_1993_2309/ reg_1993_2309_en.pdf (accessed: July 24, 2017).

[21] WMA Declaration of Helsinki - Ethical Principles for Medical Research Involving Human Subjects. Available from: https:// www.wma.net/policies-post/wma-declaration-of-helsinki-ethical-principles-for-medical-research-involving-human-subjects/ (accessed: July 24, 2017).

[22] The $2005 \mathrm{XCV}$ Law regarding the modifications of the laws regulating the medicine products for human use. [2005. évi XCV. törvény az emberi alkalmazásra kerülő gyógyszerekről és egyéb, a gyógyszerpiacot szabályozó törvények módosításáról.] Available from: https://net.jogtar.hu/jr/gen/hjegy_doc.
cgi?docid=A0500095.TV (accessed: July 24, 2017). [Hungarian]

[23] The 15/2012 Ministry of Human Capacities regulation of the pharmacovigilance of the medicine products for human use. [15/2012. (VIII. 22.) EMMI rendelet az emberi alkalmazásra kerülő gyógyszerek farmakovigilanciájáról.] Available from: https://net.jogtar.hu/jr/gen/hjegy_doc.cgi?docid=al200015. emm (accessed: July 24, 2017). [Hungarian]

(Torzsa Péter dr.,

Budapest, Kútvölgyi út 4., 1125 e-mail: torzsa.peter@med.semmelweis-univ.hu)

\section{Zalaegerszegi praxis eladó}

Zalaegerszeg kertvárosában TEK-el rendelkező, 2700 kártyás praxis teljes informatikai hálózattal eladó.

Ár megegyezés szerint.

Érdeklödni a következő telefonszámon lehet: +36 303488744

\section{Felhívás előfizetésre}

Legyen Olvasónk a következő évben is!

Fizessen elő az Orvosi Hetilap 2018-as évfolyamára!

Egy füzet ára: $950 \mathrm{Ft}$.

Éves előfizetési dij: $39900 \mathrm{Ft}$, nyugdijjasoknak: $29925 \mathrm{Ft}$.

Az online változat éves előfizetési dija: $24990 \mathrm{Ft}$. 